\title{
STOROSIOS IR TIESIOSIOS ŽARNOS VĖŽYS: DIAGNOSTIKA IR GYDYMAS
}

\author{
Tomas Staniulis, Austėja Rimkutė, Eglè Bylaitė \\ Lietuvos sveikatos moksly universiteto Medicinos akademija, Medicinos fakultetas
}

Raktažodžiai: tiesiosios žarnos vėžys, storosios žarnos vèžys, diagnostika, gydymas.

\section{Santrauka}

Kolorektalinis vėžys - piktybinis navikas, susiformuojantis storojoje ar tiesiojoje žarnoje. Tai trečia pagal dažnį onkologinè liga pasaulyje. Kolorektalinis vėžys pasaulyje yra ketvirtoji iš dažniausių vyrų mirties nuo onkologinių ligų priežasčių ir trečioji - moterų. Darbo tikslas - susipažinti su kolorektalinio vėžio diagnostika ir gydymu. Atlikta mokslinès literatūros apžvalga ir analizè. Tyrimo rezultatai parodè, kad dažniausi patologijos rizikos veiksniai yra paciento amžius, šeiminè anamnezè, uždegiminès žarnyno ligos ir anksčiau taikyta spindulinè terapija. Simptomai nèra specifiški pilvo skausmas, kraujas su išmatomis, skausmingas tuštinimasis ar pasikeitusi išmatų konsistencija bei tuštinimosi dažnis. Galimas pykinimas ar vėmimas, apetito stoka. Auksinis diagnostikos standartas yra kolonoskopija, tačiau prieš operaciją, siekiant nustatyti naviko išplitimą ir tikslią lokalizaciją, atliekamas kompiuterinès tomografijos tyrimas. Storosios žarnos vèžio gydymas yra chirurginis. Taikant laparoskopinę ar atviro tipo operaciją, pašalinama žarnos dalis su naviku ir sritiniais limfmazgiais. Tiesiosios žarnos gydymas taip pat chirurginis. Neoadjuvantine terapija yra vertingas lokalaus išplitusio rektalinio naviko gydymo metodas. Šiuo metu nėra bendro sutarimo, ar neoadjuvantinis gydymas yra efektyvus, esant radikaliai rezekuotam storosios žarnos véžiui. Po operacijos gali būti skiriama adjuvantinè terapija. Paprastai taikomas chemoterapijos kursas. Jo tikslas - sunaikinti mikrometastazinius židinius, kurių nepašalino rezekcija. Adjuvantinè chemoterapija yra efektyviausia pacientams, sergantiems III stadijos, ị limfmazgius išplitusiu vėžiu. Tokiu atveju rekomenduojamas chemoterapijos kursas, ị kurị įeina oksaliplatinos preparatas. Paprastai chemoterapijos kurso trukmė yra šeši mėnesiai. Chemoterapinis gydymas sukelia daug nepageidaujamų šalutinių reiškinių, tokių kaip mukozitas, febrili neutropenija, kardiotoksinis poveikis, vėmimas ir viduriavimas, rankų-pédų sindromas. Išvados. Spindulinès terapijos nauda esant storosios žarnos vėžiui nėra kliniškai pagrịsta. Tuo storosios žarnos naviko gydymas skiriasi nuo rektalinio véžio gydymo metodikos - jo atveju spindulinè terapija laikoma efektyvi ir dažnai taikoma. Svarbiausias veiksnys, kuris lemia pooperacinę kolorektalinio vėžio gydymo baigti, yra naviko stadija.

\section{Ivadas}

Kolorektalinis vėžys (KV) - piktybinis navikas, susiformuojantis storojoje ar tiesiojoje žarnoje. Tai trečia pagal dažnị onkologinè liga, kuria kasmet pasaulyje suserga 746000 vyrų $(9,2 \%$ visų naujai diagnozuotų onkologinių ligų) ir 614000 moterų (10\%). Iš visų onkologinių susirgimų KV užima antrą vietą tarp vyrų ir trečią - tarp moterų $[1,2]$. Kolorektalinis vėžys pasaulyje yra ketvirtoji dažniausia vyrų mirties nuo onkologinių ligų priežastis ir trečioji - moterų. Dauguma (55 proc.) naujų KV atvejų diagnozuojami ekonomiškai išsivysčiusiose valstybėse. Tai siejama su dideliu gyvenimo tempu, stresu, fizinio aktyvumo stoka, rūkymu, maitinimosi ịpročiais, nutukimu $[3,4]$. Duomenys rodo, jog net 4,3 proc. žmonių populiacijos gyvenimo eigoje nustatomas šis vėžys. Tobulejjant medicinai, diagnostikos metodai darosi jautesni ir specifiškesni nei anksčiau, dèl to ligą galima aptikti ankstesnejje stadijoje. Modernèja pirminio bei metastazinio kolorektalinio véžio gydymas. İdiegtos laparoskopinès operacijos, kurios yra mažiau invazyvios bei saugesnès, nei atvirojo tipo. Atnaujinami chemoterapijos bei radioterapijos gydymo algoritmai, vykdomos profilaktinès patikros programos [5,6]. Visa tai lemia, jog nuo 1992 iki 2014 metų mirštamumas nuo kolorektalinio vėžio laipsniškai mažèja [2]. Kolorektalinis vėžys skirstomas ị storosios ir tiesiosios žarnos věžĭ. Klinikiniu požiūriu, storosios žarnos vėžys dar skirstomas ị dešinès pusès (akloji žarna, kylančioji žarna, skersine žarna) ir kaires pusès (nusileidžiančioji žarna ir riestine žarna). Tiesiosios žarnos vėžys nustatomas, kai navikas yra nutolęs nuo analinio sfinkterio iki $15 \mathrm{~cm}[7,8]$. 
Darbo tikslas - susipažinti su kolorektalinio vėžio diagnostika ir gydymu.

\section{Darbo medžiaga ir jos atrankos kriterijai}

Atlikta mokslinès literatūros apžvalga. Duomenys rinkti iš kompiuterinių bibliografinių medicininių duomenų bazių PubMed ir Science Direct. Paieška buvo vykdoma naudojant reikšminius žodžius: colorectal cancer [MeSH Terms], colorectal cancer diagnostics [MeSH Terms], treatment.

Straipsnių atrankos kriterijai: prieinama viso teksto publikacija, tekstas parašytas anglų kalba.

\section{Tyrimo rezultatai}

Kolorektalinio vėžio rizikos veiksniai. Svarbiausi rizikos veiksniai, ị kuriuos atsižvelgiama sudarant profilaktinès kolorektalinio véžio patikros rekomendacijas, yra paciento amžius, šeiminè anamnezè, uždegiminès žarnyno ligos ir anksčiau taikyta spindulinè terapija. Šeiminè adenominė polipozė ir Lynčo sindromas yra dažniausi paveldimi su kolorektalinio véžio rizika susiję sindromai $[9,10]$. Žinoma opinio kolito sąsaja su navikinèmis būklèmis. Pankolitas didina kolorektalinio véžio riziką 5-15 kartų, lyginant su bendraja populiacija [11]. Manoma, kad Krono ligos sukeltas pankolitas tiek pat didina vèžio riziką. Pacientų, sergančių cistine fibroze, $8-14$ kartų didesnè virškinamojo trakto naviko rizika (PI 8,42-14,11), kuri dar didèja po plaučių transplantacijos [12]. Nustatyta, kad žmonèms, vaikystèje sirgusiems navikinèmis būklèmis ir gydytiems abdominaline spinduline terapija, padidèja gastrointestinalinių navikų rizika (PI 2,8-6,3) [13]. Vyriška lytis ir juodaodžių kilmé taip pat siejami su didesne kolorektalinio véžio rizika [14].

Simptomai. Kolorektalinio véžio diagnostika remiasi paciento skundais bei laboratoriniais ar instrumentiniais tyrimais. Simptomai gali būti specifiniai žarnyno patologijai - pilvo skausmai, kraujas su išmatomis, skausmingas tuštinimasis ar pasikeitusi išmatų konsistencija bei tuštinimosi dažnis. Galimas pykinimas ar vėmimas, apetito stoka, tačiau pasireiškia ir sisteminiai vėžiui būdingi simptomai: svorio pokyčiai, silpnumas, anemijai būdingi kvejpavimo ar kraujotakos sutrikimai [8-10]. Svarbu paminėti, kad ankstyvose véžio stadijose eiga gali būti besimptomè, todèl vykdomos prevencinès patikros programos [4].

Diagnostika. Būtini diagnozę patvirtinantys tyrimai. Kolonoskopija yra vienas iš dažniausiai atliekamų tyrimų, laikomų aukso standartu [8].

Kolonoskopija yra plačiai paplitęs tyrimas kolorektaliniam vėžiui patvirtinti. Šis tyrimas yra tikslus, galintis patvirtinti véžio diagnozę, tačiau lyginant su imunohistocheminiais tyrimais, yra brangus, reikalaujantis papildomo pasiruošimo [4]. Tyrimas atliekamas specialų prietaisą ko- lonoskopą įstatant ị tiesiają žarną. Šio prietaiso gale esantis daviklis perduoda vaizdinę informaciją apie storosios žarnos vidinès sienelès pokyčius. Tyrimas atliekamas ir gydymo tikslais - jo metu galima šalinti adenomas ir polipus, kuriu pašalinimas siejamas su vėžio plitimo prevencija. Šis tyrimas turi pranašumą, nes jo metu aptinkami ir mažiausi pokyčiai, plokšti (3 mm virš žarnos sienelès) pakitimai. Aptikus piktybinį procesą, galima nustatyti jo lokaciją, išplitimą, paimti biopsiją histologiniam tyrimui. Tyrimui reikalingas specialus pasiruošimas, dieta, žarnyno turinio pašalinimas bei sedacija [8].

KT kolonografija plačiai naudojama dèl specifiškumo, kuris siekia 100 procentų [15]. Jei nèra kontraindikacijų, kolonografijos metu naudojamas intraveninis kontrastas. Dèl geresnès vizualizacijos procedūra atliekama ị paciento tiesiają žarną pučiant orą. Dažniausiai tyrimas atliekamas dviejose pozicijose - pacientui gulint ant nugaros ir ant pilvo [16]. Kolonografija mažai jautri pokyčiams, kurie yra mažesni, nei $9 \mathrm{~mm}$, ar plokštiems navikiniams pakitimams, kurie nuo žarnos paviršiaus pakilę mažiau nei $3 \mathrm{~mm}$. Šiam tyrimui sedacija nebūtina, tačiau reikalingas toks pat žarnyno paruošimas, kaip ir kolonoskopijos ar kapsulinès endoskopijos metu, reikalinga žarnyno turinio evakuacija, tyrimas brangus, pacientas paveikiamas radiacijos, todèl kolonografija neturi pranašumo, lyginant su kolonoskopija [8].

Kapsulinė endoskopija - tyrimas, leidžiantis vizualizuoti visą virškinamajj traktą. Šis tyrimas atliekamas praryjant mažą, ị kapsulę panašią ịrangą, kuri leidžia vizualiai apžiūrèti virškinamajji traktą [16]. Lyginant su ịprastine kolonoskopija, šis tyrimas neinvazyvus, patogus, vizualizacijos apimtis didesnè, apimanti visą žarnyną. Kapsulè sudaro 344 laipsnių kampą, leidžiantị vizualizuoti didžiają dalị žarnyno ploto [8], tačiau tyrimo metu negalima atlikti biopsijos, pašalinti polipų ar kitų audinių, todèl kolonoskopija laikoma pranašesne, diagnozuojant kolorektalini vèži [13]. Šio tyrimo specifiškumas siekia 82 proc., jautrumas 88 proc., tyrimas gali būti atliktas pacientams, kurie atsisako daryti kolonoskopiją, tačiau tyrimui galimos tokios kontraindikacijos, kaip žarnų stenozė ar nepraeinamumas, dèl kurių kapsulè negalètų pasišalinti iš paciento organizmo [16]. Norint gauti geriausius rezultatus, tyrimui reikalingas pasiruošimas bei žarnyno turinio išvalymas [13].

Sigmoidoskopija - riestinès žarnos apžiūra naudojant specialų endoskopą - sigmoidoskopą. Panašiai, kaip ir kolonoskopijos atveju, atliekant sigmoidoskopiją, galima apžiūrèti žarnos spindį, paimti biopsiją ar pašalinti polipą. Šio tyrimo apimtis kur kas mažesnè, nei kolonoskopijos. Tyrimo metu apžiūrima tik riestinè žarna, todèl esant įtarimui, kad vėžys išplitęs, rekomenduojama atlikti kolonoskopiją [16]. Lyginant su kolonoskopija, tyrimas mažiau invazyvus, pi- 
gesnis, reikalaujantis mažesnių sedacijos dozių, mažesnès gydytojo kvalifikacijos, tačiau dèl minètų trūkumų, sigmoidoskopija sumažina mirties dèl kolorektalinio véžio tikimybę 33 proc., kai kolonoskopija sumažina mirties tikimybę 59 procentais. Dèl šios priežasties, norint diagnozuoti kolorektalinį vėžį, sigmoidoskopija atliekama rečiau [13].

Kolorektaliniam vėžiui nustatyti naudojami specifiniai žymenysi [8]. Specifinių žymenų tyrimas dažniausiai yra mažai invazyvus - medžiaga tyrimui gali būti paimta iš išmatų, kraujo ar seilių, todèl šio tyrimo prieinamumas yra didelis. Vienas iš labiausiai paplitusių tyrimų - išmatų slapto kraujavimo testas (FOBT). Kolorektalinio vėžio atveju gali būti aptinkami CEA (carcinoembryonic antigen) bei CA19-9 (carbohydrate antigen) žymenys. Tačiau šie žymenys yra mažai jautrūs ir dažnai neaptinkami, esant ankstyvoms kolorektalinio vèžio stadijoms [17].

Kraujavimas išmatose yra vienas ankstyviausių kolorektalinio vėžio požymių. Šis tyrimas nèra specifinis kolorektaliniam vèžiui, tačiau juo galime nustatyti nepatikslintą žarnyno patologiją. Šiam testui nereikalingas specialus pasiruošimas, kaip kolonoskopijos atveju, tyrimai gali būti atliekami namų sąlygomis - Lietuvoje dažniausiai naudojamas imunohistocheminis iFOB slapto kraujavimo imunologinis tyrimas padeda nustatyti kraujavimą iš bet kurios virškinamojo trakto dalies. Kraujavimo iš žarnyno priežastis gali būti polipai, hemoroidiniai mazgai. Esant teigiamam slapto kraujavimo testui, atliekamas tolimesnis paciento ištyrimas sigmoidoskopu ar kolonoskopu diagnostikai patvirtinti. Lietuvoje 5074 metų žmonèms vykdoma prevencinè atrankinè storosios žarnos véžio programa $[8,18]$.

Storosios žarnos vėžio chirurginis gydymas. Storosios žarnos véžio gydymo principas yra radikalus naviko pašalinimas sveikų audinių ribose, kartu pašalinant ir pagrindines naviką maitinančias kraujagysles, bei limfagysles. Šiam tikslui pasiekti atliekamos atviros ir laparoskopinès chirurginès operacijos $[19,20]$. Operacijos tipo pasirinkimą lemia paciento anatominès savybès, operacijos skubumas bei naviko lokalizacija. Laparoskopinès operacijos yra saugesnès, pacientai gyja greičiau, nei po atviro tipo operacijų, todèl laparoskopinès taikomos dažniau [21]. Priklausomai nuo naviko lokalizacijos, atliekama dešinès arba kairès pusės hemikolektomija. Taikant hemikolektomijos operaciją, navikas rezekuojamas sveikų audinių ribose, siekiant radikaliai ji pašalinti. Proksimalinis ir distalinis rezekcijos kraštai turi būti palikti atitinkamai 5-7 cm nuo naviko [22]. Pasireiškus mechaniniam žarnų nepraeinamumui ir nesant galimybès naviko pašalinti radikaliai, taikomas paliatyvus chirurginis gydymas. Jo metu išvedama kolostoma nepraeinamumo simptomams pašalinti $[19,23]$.

Tiesiosios žarnos věžio chirurginis gydymas. Yra keli operacinio gydymo metodai, taikomi pacientams, sergantiems tiesiosios žarnos vèžiu. Priklausomai nuo onkologinès ligos stadijos, pasirenkamas tas operacijos tipas, kurị taikat, pasiekiamas radikaliausias naviko ir limfmazgių pašalinimas ir didžiausia išgyvenamumo tikimybè. Operacijų metu siekiama išsaugoti analinès angos sfinkterius, kad nenukentetų paciento gyvenimo kokybè, tačiau nesant galimybès to padaryti, suformuojama stoma [19,24,25].

Ankstyvose tiesiosios žarnos véžio stadijose rekomenduojama atlikti minimaliai invazines operacijas, tokias kaip perrektalinė endoskopinė mikrochirurgijos operacija. Operacijos metu pašalinami gerai diferencijuoti, neišplitę navikai (T1N0) $[26,27]$. Šio tipo operacijos siejamos su geresne funkcine baigtimi ir greitesniu gijimu, nei po atviro tipo operacijų [26].

Auksiniu tiesiosios žarnos navikų (T1, T2 ir T3 stadijos) gydymo standartu laikoma transanalinè totali mezorektinè ekscizija (TaTME). Šios operacijos metu per analinę angą pasiekiamas ir pašalinamas navikas ir limfmazgiai, o žarna sujungiama (galas su galu arba šonas su šonu). Šis operacijos tipas pranašus tuo, kad išsaugomas analinès angos sfinkteris, todèl pacientu gyvenimo kokybė daug geresnè, nei po visiško tiesiosios žarnos pašalinimo [28-30].

Vèlyvosiose véžio stadijose dažniausiai atliekama radikali arba paliatyvi laparoskopinè ar atviro tipo operacija, kurios metu ekscizuojama visa tiesioji žarna su limfmazgiais, suformuojama stoma. Po šių, didelès apimties ir traumuojančių operacijų, pacientai gyja letai, dažnos pooperacinès komplikacijos, nukenčia gyvenimo kokybè.

Neoadjuvantinė (priešoperacinė) terapija yra pagrịstas lokalaus išplitusio rektalinio véžio gydymo metodas. Ji ypač efektyvi esant cT3/4 stadijos rektalinei adenokarcinomai [31]. Skiriama chemoradioterapija, atskirai, arba kartu su chemoterapija. Nustatyta, kad šis metodas padeda sumažinti operacinio gydymo invazyvumą ir didina tikimybę, kad navikas bus pašalintas radikaliai. Tikètina, jog ši terapija gerina pacientų išgyvenamumo prognozę [32,33]. Nèra bendros nuomonès, ar neoadjuvantinè terapija yra naudinga, esant storosios žarnos navikui. Manoma, kad neoadjuvantinè terapija turètų būti taikoma tik tuo atveju, kai yra didelè rizika, jog storosios žarnos navikinio darinio nepavyks rezekuoti sveiko audinio ribose, kai jau prieš operaciją žinoma, jog neįmanoma pašalinti viso naviko, arba kai navikas yra neoperabilus [34]. Jeigu tikètina, jog véžinis darinys gali būti pašalintas radikaliai, rekomenduojama rinktis chirurgini gydymą [35].

Adjuvantinė terapija. Po operacijos, kurios metu, tikètina, pavyko radikaliai pašalinti navikinį židinị, gali būti taikoma adjuvantinè terapija. Paprastai taikoma chemoterapija. Jos tikslas - sunaikinti mikrometastazinius išplitimus. 
Tokiu būdu mažèja rizika, kad navikas recidyvuos, didejja visiško pasveikimo tikimybè. Adjuvantine chemoterapija yra efektyviausia pacientams, sergantiems III stadijos (išplitusiu ị limfmazgius) věžiu. Jiems rizika, kad navikas pasikartos, sumažeja 30 proc., o mirtingumas mažeja $22-32$ procentais. Adjuvantinès terapijos reikšmė gydant II stadijos navikus išlieka kontroversiška [36].

Gydymui naudojama kelių vaistų kombinacija. Esant išplitimui ị limfmazgius, rekomenduojamas chemoterapijos kursas, ị kurị įeina oksaliplatinos preparatas. Standartiškai, chemoterapijos kurso trukmè yra šeši mėnesiai. Ilgalaikẻ terapija dažnai siejama su neurotoksišku poveikiu [37]. Oksaliplatina rečiau skiriama vyresnio amžiaus pacientams. Fiziškai stipriems vyresniems pacientams fluoracilo pagrindo chemoterapija yra tiek pat naudinga, kiek jauniems [38]. Geriatriniai pacientai, kuriems yra senatvinio silpnumo sindromas arba ryškus funkcijų sutrikimas, prastai toleruoja adjuvantinę terapiją, be to, ji nèra tikslinga, atsižvelgiant ị prastą išgyvenamumo prognozę [39].

Chemoterapija siejama su sunkių komplikacijų rizika. Gydymas priešnavikiniais vaistais gali sukelti mukozitą, febrilią neutropeniją, kardiotoksinị poveikị, vemimą ir viduriavimą, rankų-pèdų sindromą (kurio metu plaštakų ir pėdų oda parausta, peršti ir lupasi). Šalutinio poveikio dažnumas ir sunkumas priklauso nuo pasirinktos vaistų kombinacijos. Dauguma nepageidaujamų reiškinių išnyksta, nutraukus adjuvantinị chemoterapini gydymą (išskyrus oksaliplatinos sukeltą periferinę neuropatiją) [40]. Ūminès oksaliplatinos sukeltos neuropatijos simptomai yra peroralinè parestezija, dispnèja, raumenų spazmai, disfagija, balso ir regos pokyčiai, fascikuliacijos ir kiti [41].

Esant storosios žarnos véžiui, spindulinès terapijos nauda nėra kliniškai pagrịsta. Tuo storosios žarnos naviko gydymas skiriasi nuo rektalinio véžio gydymo - jo atveju spindulinė terapija yra efektyvi ir dažnai taikoma. Spindulinis storosios žarnos naviko gydymas gali būti taikomas kai kuriais atvejais, pavyzdžiui, kai židinys buvo kylančiojoje arba nusileidžiančiojoje žarnos dalyje, kai atlikta neradikali naviko rezekcija arba esant T4b stadijai [35].

Išgyvenamumo prognozę lemiantys veiksniai. Svarbiausias veiksnys, lemiantis kolorektalinio véžio operacijos baigti, yra naviko stadija. Pacientams, kuriems buvo taikyta neoadjuvantinè terapija, naviko stadija po terapijos tiksliau nusako prognozę, nei stadija prieš neoadjuvantini gydymą. Be naviko stadijos, kiti svarbūs veiksniai, kurie leidžia spręsti apie išgyvenamumo prognozę, yra ekstraduralinių naviko depositų buvimas, invazija ị limfmazgius, kraujagysles (kapiliarus, venules) ar nervus, histologinè diferenciacija, priešoperacinè karcinoembrioninio antigeno (CEA) koncentracija kraujo serume, RAS ir BRAF mutacijų buvimas [21,42-44].

\section{Išvados}

1. Diagnozei patvirtinti auksinis diagnostikos standartas yra kolonoskopija, tačiau prieš operaciją, siekiant nustatyti naviko išplitimą ir tikslią lokalizaciją, atliekamas kompiuterinès tomografijos tyrimas. Storosios žarnos vèžio gydymas yra chirurginis. Taikant laparoskopinę ar atviro tipo operaciją pašalinama žarnos dalis su naviku ir sritiniais limfmazgiais.

2. Tiesiosios žarnos gydymas taip pat yra chirurginis. Neoadjuvantine terapija yra vertingas lokalaus išplitusio rektalinio naviko gydymo metodas. Po operacijos gali būti skiriama adjuvantinè terapija. Paprastai taikomas chemoterapijos kursas.

3. Adjuvantinė chemoterapija yra efektyviausia pacientams, sergantiems III stadijos, ị limfmazgius išplitusiu, vėžiu. Spindulinès terapijos nauda esant storosios žarnos vėžiui nėra kliniškai pagrista. Rektalinio vėžio gydymo atveju spindulinė terapija laikoma efektyvia ir dažnai taikoma.

\section{Literatūra}

1. Rawla P, Sunkara T, Barsouk A. Epidemiology of colorectal cancer: incidence, mortality, survival, and risk factors. Prz Gastroenterol 2019;14(2):89-103.

https://doi.org/10.5114/pg.2018.81072

2. Kuipers EJ, Rösch T, Bretthauer M. Colorectal cancer screening - optimizing current strategies and new directions. Nat Rev Clin Oncol 2013;10:130-42.

https://doi.org/10.1038/nrclinonc.2013.12

3. Brody H. Colorectal cancer. Nature 2015;521:S1-S1. https://doi.org/10.1038/521S1a

4. Bettington M, Walker N, Clouston A, Brown I, Leggett B, Whitehall V. The serrated pathway to colorectal carcinoma: current concepts and challenges. Histopathology 2013;62:367-86. https://doi.org/10.1111/his.12055

5. Vasen HFA, Tomlinson I, Castells A. Clinical management of hereditary colorectal cancer syndromes. Nat Rev Gastroenterol Hepatol 2015;12:88-97.

https://doi.org/10.1038/nrgastro.2014.229

6. Hurwitz H, Fehrenbacher L, Novotny W, Cartwright T, Hainsworth J, Heim W, et al. Bevacizumab plus irinotecan, fluorouracil, and leucovorin for metastatic colorectal cancer. N Engl J Med 2004;350:2335-42. https://doi.org/10.1056/NEJMoa032691

7. Jess T, Rungoe C, Peyrin-Biroulet L. Risk of colorectal cancer in patients with ulcerative colitis: a meta-analysis of population-based cohort studies. Clin Gastroenterol Hepatol 2012;10:639-45.

https://doi.org/10.1016/j.cgh.2012.01.010

8. van Hooft J, van Halsema E, Vanbiervliet G, Beets-Tan R, DeWitt J, Donnellan F, et al. Self-expandable metal stents for obstructing colonic and extracolonic cancer: European society of gastrointestinal endoscopy (ESGE) clinical guideline. En- 
doscopy 2014;46:990-1053.

https://doi.org/10.1055/s-0034-1390700

9. Burt RW, Leppert MF, Slattery ML, Samowitz WS, Spirio LN, Kerber RA, et al. Genetic testing and phenotype in a large kindred with attenuated familial adenomatous polyposis. Gastroenterology 2004;127:444-51.

https://doi.org/10.1053/j.gastro.2004.05.003

10. Møller P, Seppälä T, Bernstein I, Holinski-Feder E, Sala P, Evans DG, et al. Cancer incidence and survival in Lynch syndrome patients receiving colonoscopic and gynaecological surveillance: first report from the prospective Lynch syndrome database. Gut 2017;66:464-72.

https://doi.org/10.1136/gutjnl-2015-309675

11. Olén O, Erichsen R, Sachs MC, Pedersen L, Halfvarson J, Askling J, et al. Colorectal cancer in ulcerative colitis: a Scandinavian population-based cohort study. Lancet 2020;395:123-31. https://doi.org/10.1016/S0140-6736(19)32545-0

12. Yamada A, Komaki Y, Komaki F, Micic D, Zullow S, Sakuraba A. Risk of gastrointestinal cancers in patients with cystic fibrosis: a systematic review and meta-analysis. Lancet Oncol 2018;19:758-67. https://doi.org/10.1016/S1470-2045(18)30188-8

13. Henderson TO, Oeffinger KC, Whitton J, Leisenring W, Neglia J, Meadows A, et al. Secondary gastrointestinal cancer in childhood cancer survivors. Ann Intern Med 2012;156:757. https://doi.org/10.7326/0003-4819-156-11-201206050-00002

14. Jemal A, Siegel R, Xu J, Ward E. Cancer statistics, 2010. CA Cancer J Clin 2010;60:277-300. https://doi.org/10.3322/caac.20073

15. Valančienė (Rutkauskaitė) D., Mikalauskas S. Storosios žarnos vėžio atrankinès patikros metodai: kompiuterinès tomografijos kolonografija, palyginti su kolonoskopija, pacientams su teigiamu slapto kraujo išmatose testu. Pirmieji palyginamieji rezultatai VUL Santariškių klinikose. 2013.

16. Koprowski R. Overview of technical solutions and assessment of clinical usefulness of capsule endoscopy. Biomed Eng Online 2015; 14:1-23. https://doi.org/10.1186/s12938-015-0108-3

17. Alarfaj N, El-Tohamy M, Oraby H. CA 19-9 Pancreatic tumor marker fluorescence immunosensing detection via immobilized carbon quantum dots conjugated gold nanocomposite. Int $\mathrm{J}$ Mol Sci 2018;19:1162. https://doi.org/10.3390/ijms19041162

18. Ko CW, Doria-Rose VP, Barrett MJ, Kamineni A, Enewold L, Weiss NS. Screening flexible sigmoidoscopy versus colonoscopy for reduction of colorectal cancer mortality. Int J Colorectal Dis 2019;34:1273-81.

https://doi.org/10.1007/s00384-019-03300-7

19. Daher R. New trends in colorectal surgery: single port and natural orifice techniques. World J Gastroenterol 2014;20:18104. https://doi.org/10.3748/wjg.v20.i48.18104

20. Lohsiriwat V, Jitmungngan R. Enhanced recovery after surgery in emergency colorectal surgery: review of literature and current practices. World J Gastrointest Surg 2019;11:41-52.

https://doi.org/10.4240/wjgs.v11.i2.41

21. Zheng Z, Jemal A, Lin CC, Hu C-Y, Chang GJ. Comparative effectiveness of laparoscopy vs open colectomy among nonmetastatic colon cancer patients: an analysis using the National cancer data base. JNCI J Natl Cancer Inst 2015;107:dju491dju491.

https://doi.org/10.1093/jnci/dju491

22. Nelson H, Petrelli N, Carlin A, Couture J, Fleshman J, Guillem J, et al. Guidelines 2000 for colon and rectal cancer surgery. JNCI J Natl Cancer Inst 2001;93:583-96.

https://doi.org/10.1093/jnci/93.8.583

23. Sahebally SM, McKevitt K, Stephens I, Fitzpatrick F, Deasy J, Burke JP, et al. Negative pressure wound therapy for closed laparotomy incisions in general and colorectal surgery. JAMA Surg 2018;153:e183467. https://doi.org/10.1001/jamasurg.2018.3467

24. Chong JT, Kan KM, Phillips CK, Greenstein A. Ureteral catheters for colorectal surgery: influence on operative times and complication outcomes: an observational study. Investig Clin Urol 2018;59:119.

https://doi.org/10.4111/icu.2018.59.2.119

25. Chen D, Afzal N, Sohn S, Habermann EB, Naessens JM, Larson DW, et al. Postoperative bleeding risk prediction for patients undergoing colorectal surgery. Surgery 2018;164:1209-16. https://doi.org/10.1016/j.surg.2018.05.043

26. De Graaf EJR, Doornebosch PG, Tollenaar RAEM, Meershoek-Klein Kranenbarg E, de Boer AC, Bekkering FC, et al. Transanal endoscopic microsurgery versus total mesorectal excision of T1 rectal adenocarcinomas with curative intention. Eur J Surg Oncol 2009;35:1280-5. https://doi.org/10.1016/j.ejso.2009.05.001

27. Doornebosch PG, Zeestraten E, de Graaf EJR, Hermsen P, Dawson I, Tollenaar RAEM, et al. Transanal endoscopic microsurgery for T1 rectal cancer: size matters! Surg Endosc 2012;26:551-7.

https://doi.org/10.1007/s00464-011-1918-4

28. Bonjer HJ, Deijen CL, Abis GA, Cuesta MA, van der Pas MHGM, de Lange-de Klerk ESM, et al. A randomized trial of laparoscopic versus open surgery for rectal cancer. N Engl J Med 2015;372:1324-32.

https://doi.org/10.1056/NEJMoa1414882

29. Colon cancer laparoscopic or open resection study group; Buunen M, Veldkamp R, Hop WCH, Kuhry E, et al. Survival after laparoscopic surgery versus open surgery for colon cancer: long-term outcome of a randomised clinical trial. Lancet Oncol 2009;10(1):44-52.

https://doi.org/10.1016/S1470-2045(08)70310-3

30. Emile SH, Lacy FB de, Keller DS, Martin-Perez B, Alrawi S, Lacy AM, et al. Evolution of transanal total mesorectal excision for rectal cancer: from top to bottom. World J Gastrointest Surg 2018;10:28-39. 
https://doi.org/10.4240/wjgs.v10.i3.28

31. Guillem JG, Díaz-González JA, Minsky BD, Valentini V, Jeong S-Y, Rodriguez-Bigas MA, et al. cT3N0 rectal cancer: potential overtreatment with preoperative chemoradiotherapy is warranted. J Clin Oncol 2008;26:368-73.

https://doi.org/10.1200/JCO.2007.13.5434

32. Petrelli F, Trevisan F, Cabiddu M, Sgroi G, Bruschieri L, Rausa E, et al. Total neoadjuvant therapy in rectal cancer. Ann Surg 2020;271:440-8.

https://doi.org/10.1097/SLA.0000000000003471

33. Garcia-Aguilar J, Chow OS, Smith DD, Marcet JE, Cataldo PA, Varma MG, et al. Effect of adding mFOLFOX6 after neoadjuvant chemoradiation in locally advanced rectal cancer: a multicentre, phase 2 trial. Lancet Oncol 2015;16:957-66. https://doi.org/10.1016/S1470-2045(15)00004-2

34. Cukier M, Smith AJ, Milot L, Chu W, Chung H, Fenech D, et al. Neoadjuvant chemoradiotherapy and multivisceral resection for primary locally advanced adherent colon cancer: A single institution experience. Eur J Surg Oncol 2012;38:677-82.

https://doi.org/10.1016/j.ejso.2012.05.001

35. NCCN clinical practice guidelines in oncology. National Comprehensive Cancer Network. https://www.nccn.org/professionals/physician_gls/default.aspx

36. Wolmark N. Randomized trial of postoperative adjuvant chemotherapy with or without radiotherapy for carcinoma of the rectum: national surgical adjuvant breast and bowel project protocol R-02. J Natl Cancer Inst 2000;92:388-96.

https://doi.org/10.1093/jnci/92.5.388

37. André T, Boni C, Navarro M, Tabernero J, Hickish T, Topham $\mathrm{C}$, et al. Improved overall survival with oxaliplatin, fluorouracil, and leucovorin as adjuvant treatment in stage II or III colon cancer in the MOSAIC trial. J Clin Oncol 2009;27:3109-16. https://doi.org/10.1200/JCO.2008.20.6771

38. Sargent DJ, Goldberg RM, Jacobson SD, Macdonald JS, Labianca R, Haller DG, et al. A pooled analysis of adjuvant chemotherapy for resected colon cancer in elderly patients. $\mathrm{N}$ Engl J Med 2001;345:1091-7.

https://doi.org/10.1056/NEJMoa010957

39. Hurria A, Togawa K, Mohile SG, Owusu C, Klepin HD, Gross $\mathrm{CP}$, et al. Predicting chemotherapy toxicity in older adults with cancer: a prospective multicenter study. J Clin Oncol 2011;29:3457-65.

https://doi.org/10.1200/JCO.2011.34.7625

40. Dermitzakis EV, Kimiskidis VK, Eleftheraki A, Lazaridis G, Konstantis A, Basdanis G, et al. The impact of oxaliplatin-based chemotherapy for colorectal cancer on the autonomous nervous system. Eur J Neurol 2014;21:1471-7.

https://doi.org/10.1111/ene.12514

41. Argyriou AA, Cavaletti G, Briani C, Velasco R, Bruna J, Campagnolo $\mathrm{M}$, et al. Clinical pattern and associations of oxaliplatin acute neurotoxicity. Cancer 2013;119:438-44.

https://doi.org/10.1002/cncr.27732
42. Chapuis PH, Dent OF, Fisher R, Newland RC, Pheils MT, Smyth $\mathrm{E}$, et al. A multivariate analysis of clinical and pathological variables in prognosis after resection of large bowel cancer. Br J Surg 1985;72:698-702.

https://doi.org/10.1002/bjs.1800720909

43. Betge J, Pollheimer MJ, Lindtner RA, Kornprat P, Schlemmer $\mathrm{A}$, Rehak $\mathrm{P}$, et al. Intramural and extramural vascular invasion in colorectal cancer. Cancer 2012;118:628-38.

https://doi.org/10.1002/cncr.26310

44. Thirunavukarasu P, Sukumar S, Sathaiah M, Mahan M, Pragatheeshwar KD, Pingpank JF, et al. C-stage in colon cancer: implications of carcinoembryonic antigen biomarker in staging, prognosis, and management. JNCI J Natl Cancer Inst 2011;103:689-97. https://doi.org/10.1093/jnci/djr078

\section{COLORECTAL CANCER. DIAGNOSTICS AND TREATMENT}

T. Staniulis, A. Rimkutė, E. Bylaitè

Keywords: colon cancer, rectal cancer, diagnostics, treatment. Summary

Colorectal cancer is a malignant tumour that develops in colon and rectum. It is the third most common cancer in the world. Colorectal cancer is fourth most common reason of death from cancer amongst males and third most common among females. Most common risk factors include patients' age, family history, inflammatory bowel diseases and a history of radiotherapy. Symptoms are not specific for this disease as most common are stomach-ache, stools with blood, painful evacuation of bowel or change in bowel consistency and frequency. Furthermore, nausea, vomiting and loss of appetite may occur. Golden standard for diagnosis is colonoscopy, however CT colonography is necessary before operation to determine localisation and spreading of cancer. Colon cancer treatment is surgical. Cancerous tissue with or without lymph nodes is excised during laparoscopy or open surgery. Surgery is also performed in case of rectal tumour. Neoadjuvant (preoperative) therapy is an effective treatment for locally advanced rectal cancer. However, there is no consensus if neoadjuvant therapy successfully treats colon tumors. Meanwhile, adjuvant therapy is administered after the surgery. The aim of adjuvant therapy is to destroy micrometastatic tissue which wasn't resected during the surgical procedure. Postoperative treatment is especially effective in cases of stage III tumours with invasion to lymph nodes. Oxaliplatin based treatment is considered to be the best option in case of stage III cancer. The standard course of treatment is 6 months. However, chemotherapy is associated with multiple side effects such as mucositis, febrile neutropenia, cardiotoxicity, nausea, vomiting, diarrhea and hand-foot syndrome. Benefits of radiation therapy to treat resected colon cancer with negative margins are low. On the other hand, rectal cancer is often treated with postoperative radiotherapy as the treatment is found to be highly effective. The most important prognostic factor of the outcome of colorectal cancer is a pathologic stage at presentation.

Correspondence to: staniulis.tomas@gmail.com

Gauta 2020-05-26 